\title{
Highly reversible lead-carbon battery anode with lead grafting on the carbon surface
}

\author{
Jian Yin ${ }^{\mathrm{a}}$, Nan Lin ${ }^{\mathrm{b}}$, Wenli Zhang ${ }^{\mathrm{a}, 1}$, Zheqi Lin ${ }^{\mathrm{a}}$, Ziqing Zhang ${ }^{\mathrm{a}}$, Yue Wang ${ }^{\mathrm{a}}$, Jun Shi ${ }^{\mathrm{a}}$, Jinpeng Bao ${ }^{\mathrm{a}}$, Haibo Lin ${ }^{\mathrm{a}, \mathrm{c}, \mathrm{d} \text {, * }}$ \\ a College of Chemistry, Jilin University, Changchun 130012, Jilin, China \\ ${ }^{\mathrm{b}}$ Institute of Energy and Process Systems Engineering, Technische Universität Braunschweig, Franz-Liszt-Str. 35, Braunschweig, Germany \\ ${ }^{c}$ Key Laboratory of Physics and Technology for Advanced Batteries of Ministry of Education, Jilin University, Changchun 130012, Jilin, China \\ ' Guangdong Guanghua Sci-Tech Co., Ltd., Shantou 515061, Guangdong, China
}

\section{A R T I C L E IN F O}

\section{Article history:}

Received 24 December 2017

Received in revised form 4 March 2018

Accepted 5 March 2018

Available online xxx

\section{Keywords:}

Lead-carbon battery

Carbon/lead composite

Charge acceptance

Hydrogen evolution

Electrochemically active surface area

\begin{abstract}
A B S T R A C T
A novel $\mathrm{C} / \mathrm{Pb}$ composite has been successfully prepared by electroless plating to reduce the hydrogen evolution and achieve the high reversibility of the anode of lead-carbon battery (LCB). The deposited lead on the surface of $\mathrm{C} / \mathrm{Pb}$ composite was found to be uniform and adherent to carbon surface. Because lead has been stuck on the surface of $\mathrm{C} / \mathrm{Pb}$ composite, the embedded structure suppresses the hydrogen evolution of lead-carbon anode and strengthens the connection between carbon additive and sponge lead. Compared with the blank anode, the lead-carbon anode with $\mathrm{C} / \mathrm{Pb}$ composite displays excellent charge--discharge reversibility, which is attributed to the good connection between carbon additives and lead that has been stuck on the surface of $\mathrm{C} / \mathrm{Pb}$ composite during the preparation process. The addition of $\mathrm{C} / \mathrm{Pb}$ composite maintains a solid anode structure with high specific surface area and power volume, and thereby, it plays a significant role in the highly reversible lead-carbon anode.
\end{abstract}

(C) 2018 .

\section{Introduction}

Lead-acid battery (LAB) plays an important role in our daily life [1]. In the 21 st century, LAB is expected to be used in new emerging applications such as hybrid electric vehicles (HEVs) and renewable energy storage systems $[2,3]$. In renewable energy storage systems, LAB collects intermittent electricity and produces stable power. Due to the intermittent and unstable nature of renewable energy, LABs are always employed under partial-state-of-charge (PSoC) operation [4]. After a long-term operation, the anode of LAB is gradually sulfated, and the sulfate leads to the decline of both charge acceptance and capacity [5-8]. Due to the severe sulfation on the anode of LAB, it greatly impedes lead acid batteries from advanced applications in HEVs and renewable energy storage systems $[9,10]$.

Lead-carbon battery (LCB) is well known for its superior performance in PSoC operation [11-15]. The good performance of LCB is attributed to the functions of carbon materials in lead-carbon anode of LCB, i.e., improving the conductivity of electrode [16,17]; steric inhibition of sulfation $[18,19]$; enlarging porosity and electrochemical active surface area [20-22]; increasing electric double-layer capacitance [23]; and providing extra room for the diffusion of electrolyte [24-26]. In addition, carbon materials with high porosity and surface area are benefit to the increase of the contact area between anode active materials (AAMs) and the electrolyte [20-24,27].

\footnotetext{
* Corresponding author at: College of Chemistry, Jilin University, Changchun 130012, Jilin, China.

Email address: lhb910@jlu.edu.cn (H.L. Lin)

${ }^{1}$ Present address: Materials Science and Engineering, King Abdullah University of Science and Technology (KAUST), Thuwal 23955-6900, Saudi Arabia.
}

However, carbon additives in lead-carbon anode of LCB also cause the following problems, such as high hydrogen evolution rate and loose contact between lead and carbon [28-30]. The addition of carbon results in high hydrogen evolution rate of AAMs. At the end of charge process, the generated hydrogen bubbles can separate carbon particles from the lead-carbon anode. Consequently, the structure of LCB's anode is gradually destroyed [31]. The hydrogen evolution also leads to low coulombic efficiency, low energy efficiency and the water loss of electrolyte [32,33].

To inhibit the hydrogen evolution of lead-carbon anode, researchers have put forward many methods [34-43]. One method is to add the inhibitors of hydrogen evolution into the electrolyte [34-37]. Pavlov and Nikolov found that polyaspartic acid in the electrolyte can effectively slow down the hydrogen evolution rate [37]. Another method is to introduce functional groups of carbon additives to enhance hydrogen evolution overpotential. Since the electronegativity of nitrogen atom is more negative than that of carbon atom, Hong et al. restrained the hydrogen evolution using nitrogen-rich carbon materials [38]. Wang et al. explored the impact of oxygen-containing functional groups of carbon material on hydrogen evolution, and found the restraining effect of acidic groups and the promoting effect of alkaline groups [39]. In addition, some metal and metal oxides additives with high overpotential of hydrogen evolution have also been used to reduce hydrogen evolution rate. Zhao et al. explored the effect of indium oxide, gallium oxide and bismuth oxide on inhibiting the hydrogen evolution of lead-carbon anode [40-42]. Xiang et al. concluded that $\mathrm{Zn}$ (II) reduces the hydrogen evolution rate of anodes with electrochemical active carbon [43]. All these above methods have shown positive effects on reducing the hydrogen evolution rate of lead-carbon anode. However, the added inhibitors in the electrolyte may cause self-discharge reactions, and metal additives in 
AAMs can cause a problem of recycling LCB. Some other simple methods are needed be developed to reduce the hydrogen evolution rate and get the lead-carbon battery anode with excellent performance.

Lead is a kind of metal with high overpotential of hydrogen evolution (OHE). The composition of lead and carbon can improve the OHE of carbon additives. Meanwhile, lead is the main component of AAMs. Grafting lead on carbon surface strengthens the connection between carbon additives and sponge lead, thereby enhancing the stability of lead-carbon anode [27,44-48]. Researchers have prepared carbon/lead composite through various chemical deposition methods. Xue et al. made a kind of carbon/lead composite by calcining lead citrate precursor [44]. Ma et al. obtained a graphene/lead sulfate composite by soaking graphene in lead acetate and sulfuric acid solution [45]. Hong et al. prepared a nano-lead modified activated carbon composite by ultrasonic-absorption and chemical-precipitate method [27]. Tong et al. prepared a kind of activated carbon material containing divalent lead [46]. Wang et al. verified that lead can be electrodeposited into the nano-sized carbon pores and prolong the cycle life of lead-carbon battery with the lead@carbon composite [47]. Their further work about lead-doped porous carbon composite and graphite additives on the purpose of suppressing sulfation have also been reported [48]. However, the existing methods of compositing lead and carbon have some drawbacks, such as the non-uniformly deposited lead on the surface of carbon and a lack of investigations on the connections formed between carbon/lead composite and sponge lead in the anodes. On the other hand, owing to the transformation of $\mathrm{PbSO}_{4}$ and $\mathrm{Pb}$, the volume change may cause separation between carbon additive and sponge lead. As good connection between carbon and lead particles is responsible for the conductive network of lead-carbon anode, it's indispensable to investigate the effects of physical connection between carbon additive and sponge lead on electrode performance.

In this paper, rice husk-based hierarchical porous carbon (RHHPC) has been used to prepare a novel $\mathrm{C} / \mathrm{Pb}$ composite by electroless plating. The use of RHHPC with high porosity and surface area was to achieve an ideal electrochemically active surface area of the LCB anode [49]. The electroless plating method was used to synthesis continuous and dense deposited lead layer [50-52]. The homogeneously deposited lead layer on $\mathrm{C} / \mathrm{Pb}$ composite slows down the hydrogen evolution rate of lead-carbon anode and strengthens the connection between carbon additive and sponge lead. The good connection between carbon additive and sponge lead plays a significant role in maintaining porous structure of lead-carbon anode and enhancing the reversibility of LCB under PSoC operation.

\section{Experimental}

\subsection{Preparation}

\subsubsection{Preparation of the $\mathrm{C} / \mathrm{Pb}$ composite}

RHHPC was obtained as described in our previous work [49]. C/ $\mathrm{Pb}$ composite was obtained as follows [50-52]: 3.0g RHHPC was soaked in $20.0 \mathrm{~mL} 0.5 \mathrm{~mol} \mathrm{~L}^{-1} \mathrm{H}_{2} \mathrm{SO}_{4}$ solution for $10 \mathrm{~min}$ to remove impurities soluble in acid, then filtered and washed with distilled water. After sensitized in $20.0 \mathrm{~mL} 2.5 \mathrm{wt} \% \mathrm{SnCl}_{2}+4 \mathrm{wt} \% \mathrm{HCl}$ solution for $10 \mathrm{~min}$, RHHPC was soaked in $20.0 \mathrm{~mL} 0.05 \mathrm{wt} \% \mathrm{PdCl}_{2}+4 \mathrm{wt} \%$ $\mathrm{HCl}$ solution for $10 \mathrm{~min}$ to get $\mathrm{Pd}$ seeds for $\mathrm{Pb}$ to grow. After filtration and wash with distilled water, the intermediate was stirred at $60{ }^{\circ} \mathrm{C}$ for $2 \mathrm{~h}$ in a dimethylsulfoxide solution (ca. $20 \mathrm{~mL}$ ) containing $12.00 \mathrm{~g}$ lead nitrate and $2.75 \mathrm{~g}$ thiourea to complete the electroless plating. The product was obtained after filtering and drying at $80{ }^{\circ} \mathrm{C}$ overnight. The as-prepared product was marked as $\mathrm{C} / \mathrm{Pb}$ composite.

\subsubsection{Preparation of anodes}

LCBs with AAMs containing $2.00 \mathrm{~g}$ RHHPC, $2.19 \mathrm{~g} \mathrm{C} / \mathrm{Pb}$ composite (ensure the same quantity of RHHPC) were marked as RHHPC cell, $\mathrm{C} / \mathrm{Pb}$ composite cell. Besides of the above carbon additives, AAMs contained $100.00 \mathrm{~g}$ lead oxide, $0.80 \mathrm{~g}$ barium sulfate, $0.13 \mathrm{~g}$ short fiber, $0.18 \mathrm{~g}$ acetylene black, $0.20 \mathrm{~g}$ humic acid, $0.20 \mathrm{~g}$ sodium lignosulphonate, $11.50 \mathrm{~g}$ distilled water and $8.80 \mathrm{~g}$ sulfuric acid solution $(51.5 \mathrm{wt} \%)$. A blank cell with no carbon additives was also made as a reference. Specific steps of the preparation of blank anode and lead-carbon anodes were as follows: after 10 min powder mixing, water was added and mixed quickly for $3 \mathrm{~min}$. Then the acid solution was slowly added with $15-17 \mathrm{~min}$ with stirring. The pastes were pasted on $\mathrm{PbCaSn}$ grids (weighted ca. $8.70 \mathrm{~g}$ ) with a geometric surface of $40.0 \mathrm{~mm} \times 68.0 \mathrm{~mm} \times 1.5 \mathrm{~mm}$. Small-sized lead-carbon anodes with a geometric surface of $6.0 \mathrm{~mm} \times 8.0 \mathrm{~mm} \times 1.5 \mathrm{~mm}$ (weighted ca. $0.280 \mathrm{~g}$ AAMs) were also made for electrochemical tests. The curing procedure lasting ca. $45 \mathrm{~h}$ was programmed as follows: $50{ }^{\circ} \mathrm{C}$ and $98 \%$ relative humidity for $24 \mathrm{~h}, 55^{\circ} \mathrm{C}$ and $80 \%$ relative humidity for $15 \mathrm{~h}, 60{ }^{\circ} \mathrm{C}$ and $30 \%$ relative humidity for $3 \mathrm{~h}, 70{ }^{\circ} \mathrm{C}$ and $10 \%$ relative humidity for $3 \mathrm{~h}$. All cells were composed of three anodes and two cathods (ca. $27.0 \mathrm{~g}, 40.0 \mathrm{~mm} \times 68.0 \mathrm{~mm} \times 3.0 \mathrm{~mm}$ ), and were soaked in $5 \mathrm{~mol} \mathrm{~L}^{-1}$ sulphuric acid solution for $2 \mathrm{~h}$ before the formation process [59]. The formation and all tests of the cells were conducted on a battery testing system (BTS $5 \mathrm{~V} / 6 \mathrm{~A}$, Shenzhen NEWARE Electronics Co., Ltd., China). Formation processes were as follows: cells were charged at $0.0667 \mathrm{C}_{2}, 0.25 \mathrm{C}_{2}, 0.1333 \mathrm{C}_{2}$ for $1 \mathrm{~h}, 16 \mathrm{~h}, 2 \mathrm{~h}$, respectively, and discharged at $0.4167 \mathrm{C}_{2}$ to $1.8 \mathrm{~V}$. After repeating the charge-discharge process for 3 times, charged the cells at $0.125 \mathrm{C}_{2}$ for $8 \mathrm{~h}$ and $0.0417 \mathrm{C}_{2}$ for $2 \mathrm{~h}$.

\subsection{Physical characterization}

The morphologies of carbon additives and anodes were characterized by Scanning Electron Microscope (SEM, SU8020, HITACHI, Japan). Nitrogen absorption/desorption isotherms were measured by a surface physical adsorption instrument (ASAP2010 Micrometrics, USA). The specific surface areas and pore volumes of the carbon additives (RHHPC and $\mathrm{C} / \mathrm{Pb}$ composite) and the anodes were calculated by the Brunauer-Emmett-Teller (BET) and Barrette-Joynere-Halenda (BJH) method, respectively. Energy Dispersive X-ray spectroscopy (EDX) was used to test the combination of lead and carbon. The resistivity values of RHHPC and $\mathrm{C} / \mathrm{Pb}$ composite were measured by a four-probe semiconductor-powder resistivity instrument (ST-2722, Suzhou Jingge Electronics Co., Ltd. China).

\subsection{Electrochemical tests}

Electrochemical performances were tested on an electrochemical workstation (PARSTAT 2273, Princeton Applied Research, USA). Working electrodes were the small-sized lead-carbon anodes with the geometric size of $6.0 \mathrm{~mm} \times 8.0 \mathrm{~mm} \times 1.5 \mathrm{~mm}$ (the same grids, paste and mass loading as mentioned above in part 2.1.2). A commercial pasted type $\mathrm{PbO}_{2}$ (ca. $27.0 \mathrm{~g}$ active materials, $40.0 \mathrm{~mm} \times 68.0 \mathrm{~mm} \times 3.0 \mathrm{~mm}$ ) electrode was used as counter electrode. A mercurous sulfate electrode (MSE, $\mathrm{Hg} / \mathrm{Hg}_{2} \mathrm{SO}_{4} / \mathrm{K}_{2} \mathrm{SO}_{4}$, saturated, $0.658 \mathrm{~V}$ vs. $\mathrm{SHE}$ ) was used as reference electrode. Hydrogen evolution rate of the anodes was evaluated by linear sweep voltammetry (LSV) and electrochemical impedance spectroscopy (EIS). After 20 min polarization at $-1.20 \mathrm{~V}$, EIS was measured at the frequency range of $100 \mathrm{kHz}-0.1 \mathrm{~Hz}$ with a voltage amplitude of $10 \mathrm{mV}$. LSV 
was tested within the range of $-1.40 \mathrm{~V}$ and $-1.10 \mathrm{~V}$ at a scan rate of $10 \mathrm{mV} \mathrm{s}^{-1}$. Cyclic voltammetry $(\mathrm{CV})$ profiles were tested within the range of $-1.50 \mathrm{~V}$ and $-0.60 \mathrm{~V}$ at scan rates of $1 \mathrm{mV} \mathrm{s}^{-1}, 5 \mathrm{mV} \mathrm{s}^{-1}$ and $10 \mathrm{mV} \mathrm{s}^{-1}$, respectively. All electrochemical tests of lead-carbon anodes and lead-carbon cells were conducted in the $5.0 \mathrm{~mol} \mathrm{~L}^{-1}$ sulphuric acid solution.

\subsection{Performances of the cells}

Cell performances were tested on the battery testing system (BTS $5 \mathrm{~V} / 6 \mathrm{~A}, \mathrm{NEWARE}$, China). In case of the rate capability test, active mass of each anode was $18.0 \pm 0.1 \mathrm{~g}$ and for PSoC operation, each active mass of the anode was $14.0 \pm 0.1 \mathrm{~g}$. The active mass of each anode was calculated by the weight of whole dry plate minus the weight of grid. The AGM separator was used and the cells were sealed after the formation process. The charged-operation procedures of cells were as follows: $0.3 \mathrm{C}_{1}$ constant current charging to $2.4 \mathrm{~V}$, then charging at the constant voltage of $2.4 \mathrm{~V}$ for $6 \mathrm{~h}$.

To evaluate rate capabilities and the performances under PSoC operation of the cells with RHHPC and $\mathrm{C} / \mathrm{Pb}$ composite additives, galvanostatic charge-discharge tests were used in this research. Before the rate capability test, the outer two anodes were removed after formation, thus the anode (active mass of each anode was $18.0 \pm 0.1 \mathrm{~g}$ ) was a capacity-limiting factor of LCB. Then cells were discharged at $0.1 \mathrm{C}_{10}, 1 \mathrm{C}_{1}, 0.5 \mathrm{C}_{2}$ and $0.1 \mathrm{C}_{10}$ rates. Under PSoC operation, each of the $3.8 \mathrm{Ah}$ (evaluated at $0.1 \mathrm{C}_{10}$ rate) cells was composed of three anodes (active mass of each anode was $14.0 \pm 0.1 \mathrm{~g}$ ) and two commercial cathodes (active mass of each plate was ca. $27.0 \mathrm{~g}$ ). For the PSoC test, cells were operated under $0-80 \%$ SoC: (1) Fully charge the cells, and then discharge cells to $1.8 \mathrm{~V}$ at $0.1 \mathrm{C}_{10}$ rate; (2) After resting for $5 \mathrm{~h}$, charge the cells at $0.1 \mathrm{C}_{10}$ rate with a voltage limit of $2.4 \mathrm{~V}$ for $8 \mathrm{~h}$; (3) Discharge the cells at $0.1 \mathrm{C}_{10}$ rate to $1.8 \mathrm{~V}$; (4) Repeat step (2) and (3) for 4 times, then examine the capacity of cells with step (1); (5). Repeat step (4) for continuous PSoC operations [53].

\section{Results and discussion}

RHHPC with superior electrochemical capacitive property, as the precursor of $\mathrm{C} / \mathrm{Pb}$ composite, has been reported in our previous work [52]. Morphologies of RHHPC and $\mathrm{C} / \mathrm{Pb}$ composite are shown in Fig. 1. The particle size of RHHPC is from a hundred micron-meters to few tenths of micron-meters or even less. The wide range of particle distribution is beneficial to the compact stack of AAMs. Porous structure of RHHPC resulting from the vascular bundle of rice husk can increase the pore volume of lead-carbon anode and strengthen the ionic transport $[23,24]$. The $\mathrm{C} / \mathrm{Pb}$ composite (Fig. 1d-f) show almost the same particle sizes and structures compared with RHHPC (Fig. $1 \mathrm{a}-\mathrm{c})$. The similar visible structures of RHHPC and $\mathrm{C} / \mathrm{Pb}$ composite illustrate that the deposited lead layer on $\mathrm{C} / \mathrm{Pb}$ composite may be thin and uniform. Furthermore, compared with RHHPC, the rougher surface of $\mathrm{C} / \mathrm{Pb}$ composite may be caused by the deposited lead on the
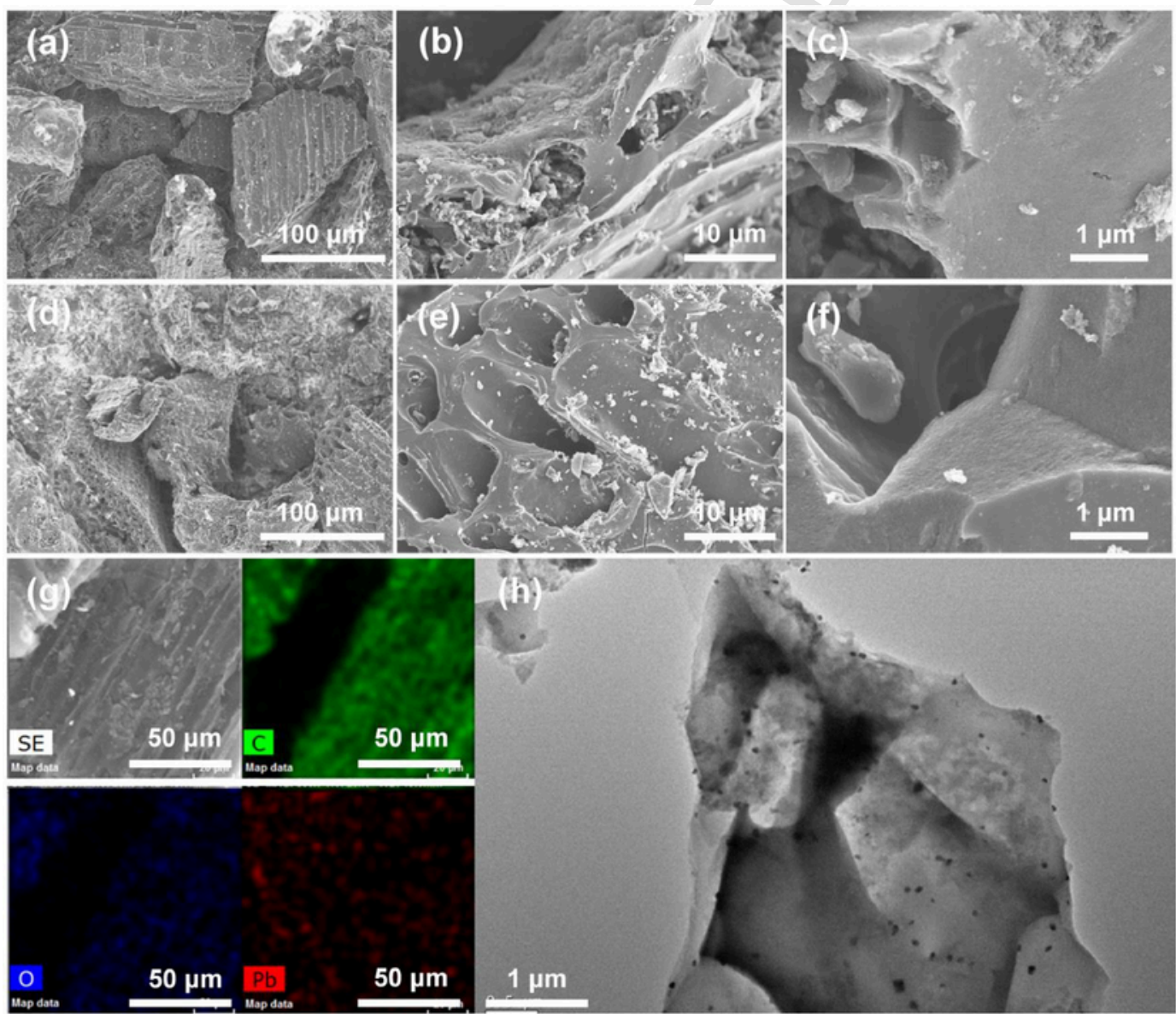

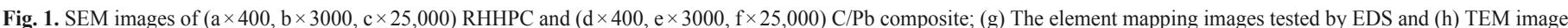
$(\times 4000)$ of $\mathrm{C} / \mathrm{Pb}$ composite. 
surface of $\mathrm{C} / \mathrm{Pb}$ composite (Fig. 1c and $\mathrm{f}$ ). Element mapping images tested by EDS and the TEM image of $\mathrm{C} / \mathrm{Pb}$ composite verified that lead is uniformly deposited on $\mathrm{C} / \mathrm{Pb}$ composite (Fig. 1g and $\mathrm{h}$ ). The mass percentages of the deposited lead on the $\mathrm{C} / \mathrm{Pb}$ composite measured by EDS technique is $9.59 \mathrm{wt} \%$.

Micro-structures of RHHPC and C/Pb composite were tested by $\mathrm{N}_{2}$ adsorption/desorption. The isotherms of RHHPC and $\mathrm{C} / \mathrm{Pb}$ composite are a combination of I/IV types with hysteresis loops, demonstrating the hierarchical pore structures of RHHPC and $\mathrm{C} / \mathrm{Pb}$ composite with rich micropores and mesopores. In addition, the pore volume of $\mathrm{C} / \mathrm{Pb}$ composite is lower than that of the RHHPC at each pore width (Fig. $2 \mathrm{~b}$ and Table 1). The decreased pore volume of $\mathrm{C} / \mathrm{Pb}$ composite at each pore width (Fig. 2b) suggests that lead is deposited on the surface of $\mathrm{C} / \mathrm{Pb}$ composite, which is in accordance with the results tested by EDS. The decrease of microporous volume can be benefit for reducing the active sites of hydrogen evolution [31]. The enlarged average pore size can enhance the ionic diffusion in electrolyte. Since the resistivity of lead $\left(2.07 \times 10^{-5} \Omega \mathrm{cm}\right)[54]$ is lower than the resistivity of RHHPC $(0.189 \Omega \mathrm{cm})$, the enhanced conductivity of $\mathrm{C} / \mathrm{Pb}$ composite can enhance the charge conduction of the interface between carbon and lead (Fig. 2c and Table 1). The density of $\mathrm{C} / \mathrm{Pb}$ composite is twice as the density of RHHPC. High density of $\mathrm{C} / \mathrm{Pb}$ composite can be capable for the homogeneous distribution of $\mathrm{C} / \mathrm{Pb}$ composite in AAMs $[27,61,62]$.

The LSV and EIS were used to evaluate the hydrogen evolution behaviors of blank, RHHPC and C/Pb composite electrodes. In LSV test, current value of the $\mathrm{C} / \mathrm{Pb}$ composite electrode is lower than that of the RHHPC electrode at the same potential (Fig. 3). At $-1.40 \mathrm{~V}$, the corresponding current values of blank, RHHPC and $\mathrm{C} / \mathrm{Pb}$ composite electrodes are $-0.072 \mathrm{~A} \mathrm{~g}^{-1},-0.353 \mathrm{~A} \mathrm{~g}^{-1}$ and $-0.168 \mathrm{~A} \mathrm{~g}^{-1}$, respectively. Obviously, the hydrogen evolution rate of $\mathrm{C} / \mathrm{Pb}$ composite electrode is lower than that of RHHPC electrode.

EIS of each anode at $-1.20 \mathrm{~V}$ is present ed as Nyquist plot (Fig. $3 \mathrm{~b}-\mathrm{d}$ ) and is fitted by the equivalent circuit diagram (iFig. 4) [31]. $R_{\mathrm{S}}$ denotes the interfacial and electrolyte resistance. $Q_{\mathrm{f}}$ and $R_{\mathrm{f}}$ are the non-ideal capacitance and the resistance of passive layer [63]. $Q_{\mathrm{dl}}$ is the non-ideal electric double layer capacitance of AAMs/electrolyte. $R_{\text {ct }}$ denotes the charge transfer resistance of reaction occurring on the electrode. At $-1.20 \mathrm{~V}$, the main reaction of the fully charged anode of LCB is hydrogen evolution, so $R_{\mathrm{ct}}$ represents the charge transfer resistance of hydrogen evolution. The value of $R_{\mathrm{ct}}$ for blank, RHHPC and $\mathrm{C} / \mathrm{Pb}$ composite electrodes are $114.6 \Omega, 19.9 \Omega$ and $42.5 \Omega$, respectively. The result illustrates that the $\mathrm{OHE}$ of $\mathrm{C} / \mathrm{Pb}$ composite electrode is higher than that of RHHPC electrode. In summary, $\mathrm{C} / \mathrm{Pb}$ composite can efficiently reduce the hydrogen evolution rate of lead-carbon anode within the working potential of LCB anode.

$\mathrm{CV}$ tests were used to elucidate the role of $\mathrm{C} / \mathrm{Pb}$ composite in charge and discharge cycles (Fig. 5) [20,56]. With the increases in scan rates, the anodic peaks shift to positive direction and the cathodic peaks shift to negative direction. The deviations of anodic and cathodic peaks in $\mathrm{CV}$ profiles demonstrate that the anodes are highly porous [31]. At the scan rate of $10 \mathrm{mV} \mathrm{s}^{-1}$, potentials for typical anodic peaks of the blank, RHHPC and $\mathrm{C} / \mathrm{Pb}$ composite electrodes are $-0.74 \mathrm{~V},-0.70 \mathrm{~V}$ and $-0.69 \mathrm{~V}$, respectively. Potentials of anodic peaks suggest that both the RHHPC and $\mathrm{C} / \mathrm{Pb}$ composite electrodes are more porous than the blank electrode. Notably, specific currents of anodic and cathodic peaks of the RHHPC and $\mathrm{C} / \mathrm{Pb}$ composite electrodes are higher than that of the blank electrode (Table 3). It indicates that the lead-carbon anodes have higher electrochemically active surface areas and better charge and discharge abilities than the blank electrode $[29,57]$. Ratios of absolute cathodic and anodic peak currents $\left(\left|I_{R}\right|\right)$ $\left.\left|I_{\mathrm{O}}\right|\right)$ expressed the reversibility on charge and discharge of anodes of LCBs (Table 3). The $\left|I_{\mathrm{R}}\right| /\left|I_{\mathrm{O}}\right|$ ratios of blank, RHHPC and $\mathrm{C} / \mathrm{Pb}$ composite electrodes are $0.53,0.84$ and 0.82 , respectively. It suggests that the $\mathrm{RHHPC}$ and $\mathrm{C} / \mathrm{Pb}$ composite are responsible for improving the reversibility on charge and discharge of anodes of LCBs.

The reversibility of $\mathrm{Pb} / \mathrm{PbSO}_{4}$ depends on the formation and dissolution of $\mathrm{PbSO}_{4}$. The formation and dissolution of $\mathrm{PbSO}_{4}$ are determined by a number of parameters such as diffusion of $\mathrm{Pb}^{2+}$ ions, electron conduction, reduction of $\mathrm{PbSO}_{4}$ and oxidization of $\mathrm{Pb}^{2+}$ ions [29]. The effect of $\mathrm{C} / \mathrm{Pb}$ composite on electrochemical reversibility of $\mathrm{Pb} / \mathrm{PbSO}_{4}$ redox was investigated by EIS at open circuit potential of the anode of LCB and presented in Fig. 6. The same equivalent circuit model is used as shown in Fig. 4. At the open circuit potential of $\mathrm{Pb}$ anode, the main reaction is the electron transfer of $\mathrm{Pb} / \mathrm{PbSO}_{4}$ redox [55]. Thus, $R_{\mathrm{ct}}$ represents the charge transfer resistance of $\mathrm{Pb} / \mathrm{PbSO}_{4}$. The values of $R_{\mathrm{ct}}$ for blank, RHHPC and $\mathrm{C} / \mathrm{Pb}$ composite electrodes are $3.0 \Omega, 2.5 \Omega$ and $1.7 \Omega$. Theoretically, the addition of high-specific-area RHHPC can have a better effect on enlarging electrochemically active surface area and the $R_{\mathrm{ct}}$ value of RHHPC electrode should be the lowest of all. However, the lowest $R_{\mathrm{ct}}$ value of all belongs to $\mathrm{C} /$ $\mathrm{Pb}$ composite electrode indicates the largest electrochemically active surface area and the best charge acceptance of $\mathrm{C} / \mathrm{Pb}$ composite electrode. The high specific surface area and pore volume of $\mathrm{C} / \mathrm{Pb}$ composite electrode are attributed to the good connection between $\mathrm{C} / \mathrm{Pb}$ composite and sponge lead [58-60]. On the other hand, different interface resistances between electrode and electrolyte can be identified from the EIS results [26]. The ohmic resistance $R_{\mathrm{S}}$ values of the blank, RHHPC and $\mathrm{C} / \mathrm{Pb}$ composite electrodes are $0.32 \Omega, 0.25 \Omega$ and 0.26 $\Omega$, respectively. The low $R_{\mathrm{s}}$ values of the RHHPC and $\mathrm{C} / \mathrm{Pb}$ composite electrodes stem from the good ionic diffusions in electrolyte.

Rate capabilities and PSoC operations of the cells were used to elucidate the impact of $\mathrm{C} / \mathrm{Pb}$ composite on $\mathrm{LCB}$. The initial capacities of cells are ca. $2.5 \mathrm{Ah}$ at $0.1 \mathrm{C}_{10}$ rate, while the capacities at $1 \mathrm{C}_{1}$ rate of the blank, RHHPC and $\mathrm{C} / \mathrm{Pb}$ composite cells are ca. 1.20 Ah, 1.26 Ah and 1.58 Ah (Fig. 7a). The high discharge capacity of $\mathrm{C} / \mathrm{Pb}$ composite cell is in accordance with the results of CV. Under PSoC operation, the initial $100 \%$ deep of discharge (DoD) capacities of the
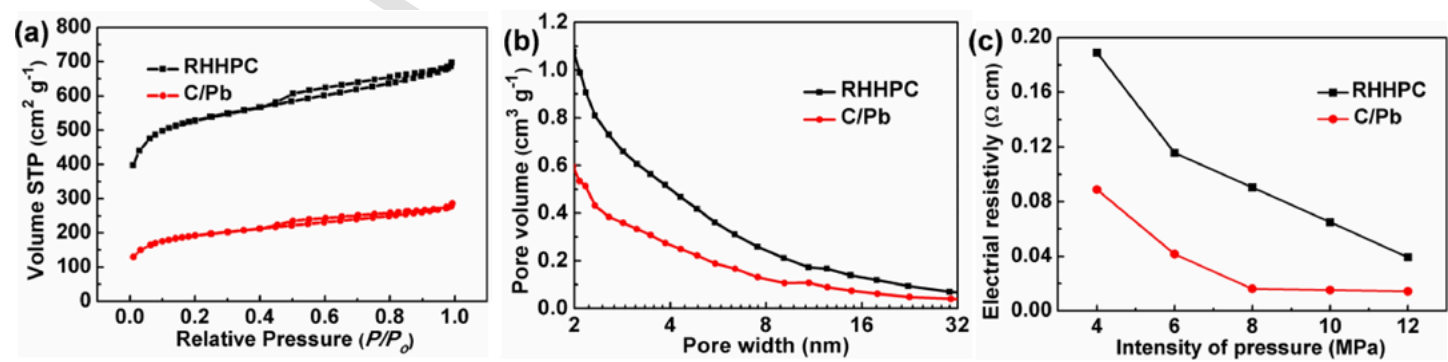

Fig. 2. (a) Nitrogen adsorption/desorption isotherms, (b) pore-size distributions and (c) resistivities of the RHHPC and the C/Pb composite. 
Table 1

Micro-structures and resistivities of the RHHPC and the $\mathrm{C} / \mathrm{Pb}$ composite.

\begin{tabular}{lllllll}
\hline & $V_{\text {micro }}$ & $V_{\text {meso }}$ & $S_{\text {BET }}$ & $D_{\text {pore }}$ & Resistivity $^{\text {a }}$ & Density \\
\hline & $\left(\mathrm{cm}^{3} \mathrm{~g}^{-1}\right)$ & $\left(\mathrm{cm}^{3} \mathrm{~g}^{-1}\right)$ & $\left(\mathrm{m}^{2} \mathrm{~g}^{-1}\right)$ & $(\mathrm{nm})$ & $(\Omega \mathrm{cm})$ & $\left(\mathrm{g} \mathrm{cm}^{-3}\right)$ \\
\hline RHHCP & 0.517 & 0.529 & 1813.6 & 2.3 & 0.19 & 0.26 \\
C/Pb composite & 0.138 & 0.283 & 669.7 & 2.5 & 0.09 & 0.53 \\
\hline
\end{tabular}

a The resistivities are the values tested at $4.0 \mathrm{MPa}$.

Table 2

The simulated results of EIS at $-1.20 \mathrm{~V}$ (vs. MSE).

\begin{tabular}{lllllllll}
\hline Cell & $R_{\mathrm{s}}$ & $Q_{\mathrm{f}}$ & $n$ & $R_{\mathrm{f}}$ & $Q_{\mathrm{dl}}$ & $n$ & $R_{\mathrm{ct}}$ & $\chi^{2}$ \\
\hline & $(\Omega)$ & $\left(\Omega^{-1} \mathrm{~s}^{\mathrm{n}}\right)$ & -- & $(\Omega)$ & $\left(\Omega^{-1} \mathrm{~s}^{\mathrm{n}}\right)$ & -- & $(\Omega)$ & $\left(10^{-3}\right)$ \\
\hline Blank & 0.35 & 0.048 & 0.54 & 0.63 & 0.017 & 0.99 & 114.6 & 3.6 \\
RHHPC & 0.24 & 0.028 & 0.70 & 0.23 & 0.014 & 0.99 & 19.9 & 2.0 \\
C/Pb composite & 0.25 & 0.030 & 0.68 & 0.23 & 0.014 & 0.98 & 42.5 & 7.6 \\
\hline
\end{tabular}

blank, RHHPC and C/Pb composite cells are ca. 3.75 Ah, 4.75 Ah and 4.40 Ah (Fig. 7). The initial $100 \%$ DoD capacities suggest that the additions of RHHPC and $\mathrm{C} / \mathrm{Pb}$ composite in AAMs can improve the utilizations of AAMs. With a long-time PSoC operation, the capacities of blank and RHHPC cells decrease rapidly. At the 90th cycle, the $100 \%$ DoD discharge capacities of blank, RHHPC and C/Pb composite cells drop to ca. 1.25 Ah, 1.70 Ah and $2.75 \mathrm{Ah}$. The capacity of $\mathrm{C} / \mathrm{Pb}$ composite cell is 2.2 times of the blank cell, and 1.6 times of the RHHPC cell. Differences in capacity suggest that the $\mathrm{C} / \mathrm{Pb}$ composite cell can sustain a high reversible capacity under PSoC operation.

Under PSoC operation, in which the cells' state of charge (SoC) were operated between 0 and $80 \%$, discharge capacities of the cells in the 1st cycle are ca. 3.2 Ah (Fig. 8a). However, in the 89th cycle, discharge capacities of the blank, RHHPC and $\mathrm{C} / \mathrm{Pb}$ composite cells are ca. 1.25 Ah, 1.7 Ah and 2.25 Ah (Fig. 7b). The declines in discharge capacities are owing to the decreased charge acceptances which coincide with high charging platforms of the lead-carbon anodes $[31,61,62]$. In the 1st cycle the charge platform are almost the same, while in the 89th cycle, charging platform of the $\mathrm{C} / \mathrm{Pb}$ composite cell corresponds to a relatively low level. This suggests that the $\mathrm{C} /$ $\mathrm{Pb}$ composite has the superior effect on inhibiting sulfation and maintaining good charge acceptance of the lead-carbon anode.

The reasons for capacity reductions of anodes are attributed to the micro-structures of anodes. After the formation process, SEM images of the anodes indicate that the formed structures of RHHPC and $\mathrm{C} / \mathrm{Pb}$ composite electrodes (Fig. 9b, 9c) are quite different from the blank electrode (Fig. 9a). Visible pores on the surface of RHHPC electrode result from the separated carbon particles of RHHPC. After the formation process, specific surface areas of the blank, RHHPC and C/ $\mathrm{Pb}$ composite electrodes are $1.9 \mathrm{~m}^{2} \mathrm{~g}^{-1}, 17.8 \mathrm{~m}^{2} \mathrm{~g}^{-1}$ and $12.7 \mathrm{~m}^{2} \mathrm{~g}^{-1}$, respectively and pore volumes of the blank, RHHPC and $\mathrm{C} / \mathrm{Pb}$ composite electrodes are $0.007 \mathrm{~cm}^{3} \mathrm{~g}^{-1}, 0.019 \mathrm{~cm}^{3} \mathrm{~g}^{-1}$ and $0.015 \mathrm{~cm}^{3} \mathrm{~g}^{-1}$, respectively (Table 5 and Fig. 10). After PSoC operation, the dense surface of blank electrode (Fig. 9d) and the large particles of lead species on the RHHPC electrode (Fig. 9e) were formed. The cracks between RHHPC particles and lead species in the RHHPC electrode (Fig. 9e) and good connection between $\mathrm{C} / \mathrm{Pb}$ composite and lead
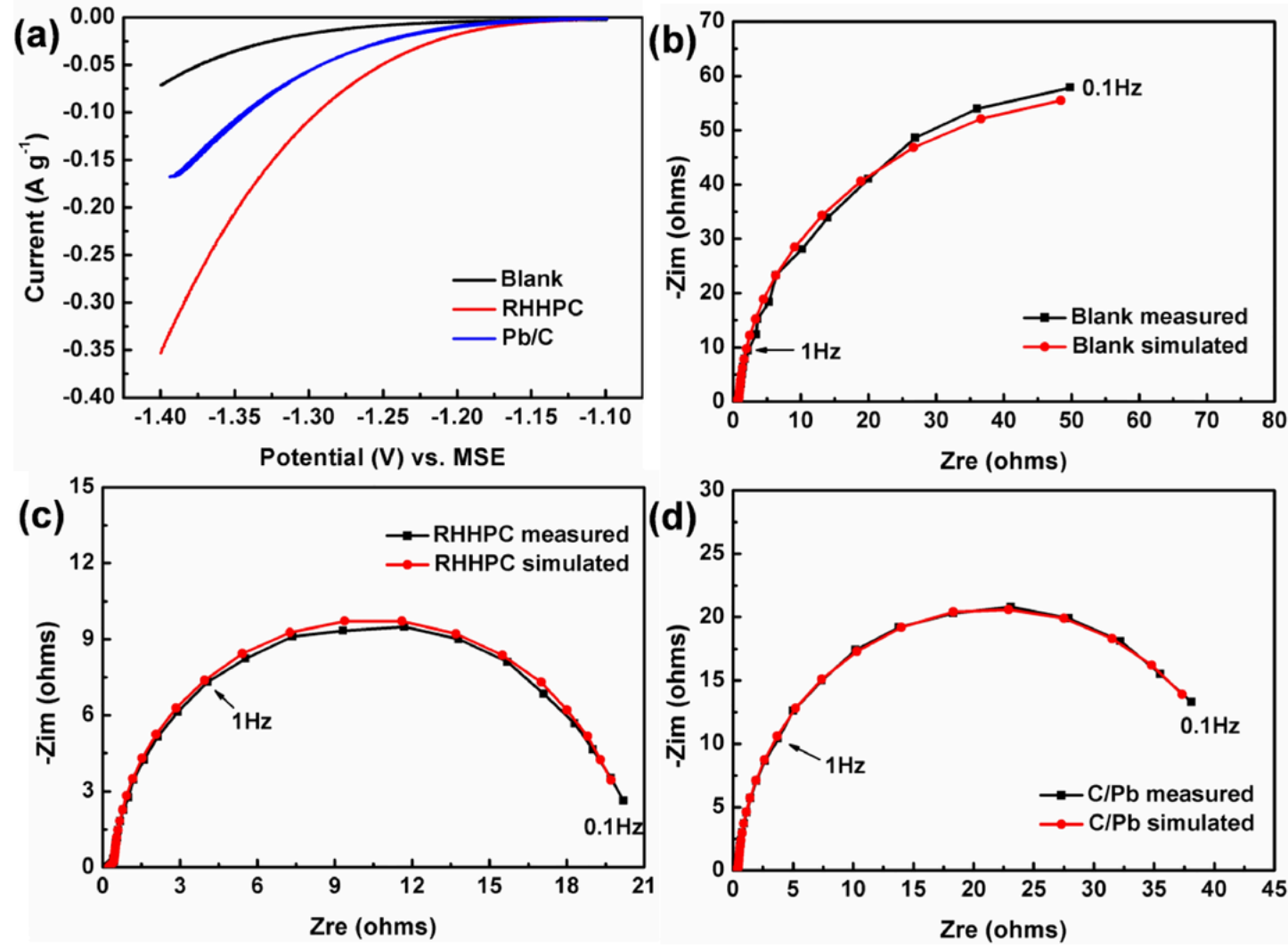

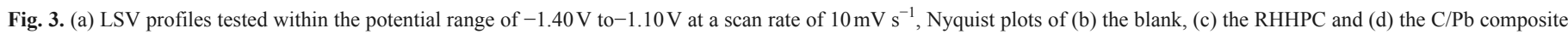
electrodes at $-1.20 \mathrm{~V}$ (vs. MSE). 


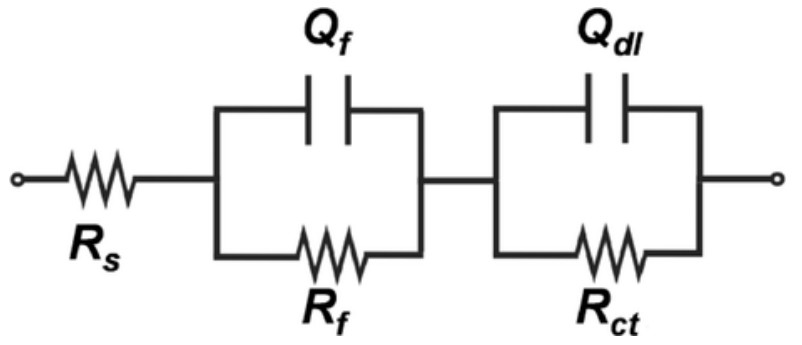

Fig. 4. The equivalent circuit.

species in the $\mathrm{C} / \mathrm{Pb}$ composite electrode (Fig. 9e) are obvious. After PSoC operation, specific surface areas of the blank, RHHPC and C/ $\mathrm{Pb}$ composite electrodes are $1.5 \mathrm{~m}^{2} \mathrm{~g}^{-1}, 19.6 \mathrm{~m}^{2} \mathrm{~g}^{-1}$ and $12.9 \mathrm{~m}^{2} \mathrm{~g}^{-1}$, respectively and pore volumes of the blank, RHHPC and C/Pb composite electrodes are $0.005 \mathrm{~cm}^{3} \mathrm{~g}^{-1}, 0.021 \mathrm{~cm}^{3} \mathrm{~g}^{-1}$ and $0.016 \mathrm{~cm}^{3} \mathrm{~g}^{-1}$, respectively (Table 5 and Fig. 10). The RHHPC and $\mathrm{C} / \mathrm{Pb}$ composite can maintain relatively high electrochemically active surface areas and porosities of the AAMs, which is in accordance with the EIS results. Micropore and mesopore volume of the RHHPC electrode after PSoC operation became higher than that after the formation process. It proves that RHHPC particles have been exposed due to poor connection between RHHPC and sponge lead. Compared with RHHPC cell, the $\mathrm{C} / \mathrm{Pb}$ composite cell has higher capacity, which results from the strengthened connection between $\mathrm{C} / \mathrm{Pb}$ composite and sponge lead.

As the AAMs are composed of skeleton network and energetic part, the skeleton network corresponds to the conducting pathway and
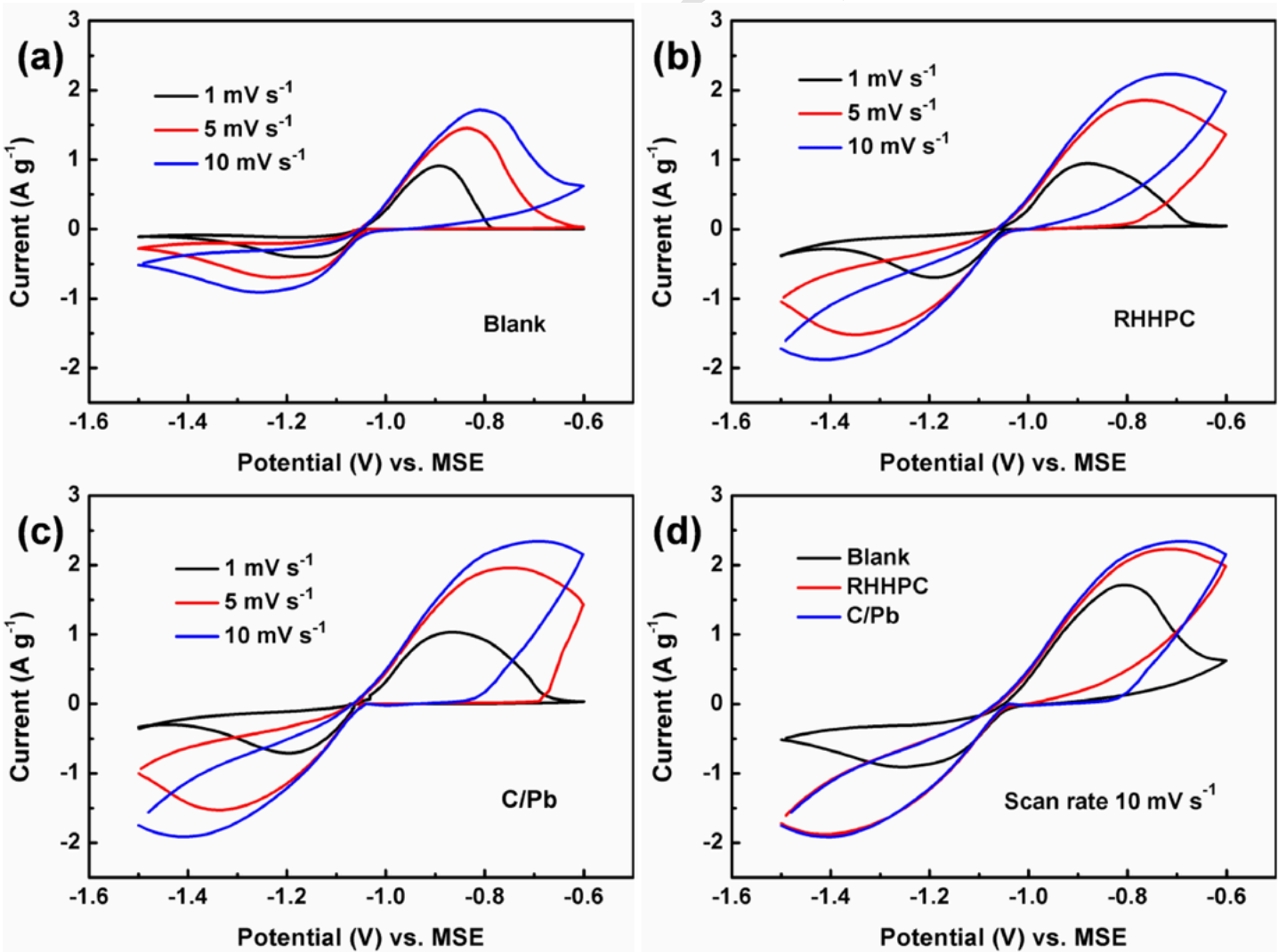

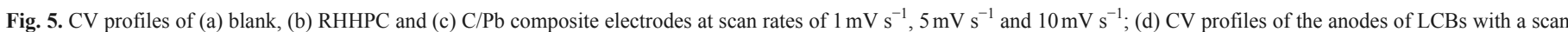
rate of $10 \mathrm{mV} \mathrm{s}^{-1}$. 
Table 3

Characteristic parameters derived from $\mathrm{CV}$ profiles at scan rate of $10 \mathrm{mV} \mathrm{s}^{-1}$.

\begin{tabular}{llll}
\hline & Anodic peak current & Cathodic peak current & $\left|I_{\mathrm{R}}\right| / I_{\mathrm{O}} \mid$ ratio \\
\hline & $\left(\mathrm{A} \mathrm{g}^{-1}\right)$ & $\left(\mathrm{A} \mathrm{g}^{-1}\right)$ & -- \\
\hline Blank & 1.72 & -0.91 & 0.53 \\
RHHPC & 2.23 & -1.80 & 0.84 \\
$\mathrm{C} / \mathrm{Pb}$ composite & 2.34 & -1.91 & 0.82 \\
\hline
\end{tabular}

Table 4

The simulated EIS results of anodes at open circuit potential.

\begin{tabular}{lllllllll}
\hline Cell & $R_{\mathrm{s}}$ & $Q_{\mathrm{f}}$ & $n$ & $R_{\mathrm{f}}$ & $Q_{\mathrm{dl}}$ & $n$ & $R_{\mathrm{ct}}$ & $\chi^{2}$ \\
\hline & $(\Omega)$ & $\left(\Omega^{-1} \mathrm{~s}^{\mathrm{n}}\right)$ & & $(\Omega)$ & $\left(\Omega^{-1} \mathrm{~s}^{\mathrm{n}}\right)$ & & $(\Omega)$ & $\left(10^{-3}\right)$ \\
\hline Blank & 0.32 & 0.030 & 0.70 & 0.20 & 0.047 & 0.86 & 3.0 & 3.2 \\
RHHPC & 0.25 & 0.019 & 0.80 & 0.10 & 0.081 & 0.72 & 2.5 & 1.4 \\
C/Pb composite & 0.26 & 0.036 & 0.69 & 0.11 & 0.073 & 0.70 & 1.7 & 1.4 \\
\hline
\end{tabular}

lead-carbon anode, $\mathrm{LCB}$ with $\mathrm{C} / \mathrm{Pb}$ composite in the anodes performed best among the cells under PSoC operation. With simple preparation method and good electrochemical behavior, $\mathrm{C} / \mathrm{Pb}$ composite has the prospect of an actual application in the anode of LCB.

\section{Uncited references}

$[28,30,57]$.

\section{Acknowledgments}

The research group acknowledges the financial support provided by National Natural Science Foundation of China (No. 21573093), National Key Research and Development Program (No. 2017YFB0307501) and Guangdong Innovative and Entrepreneurial Research Team Program (No.2013C092).
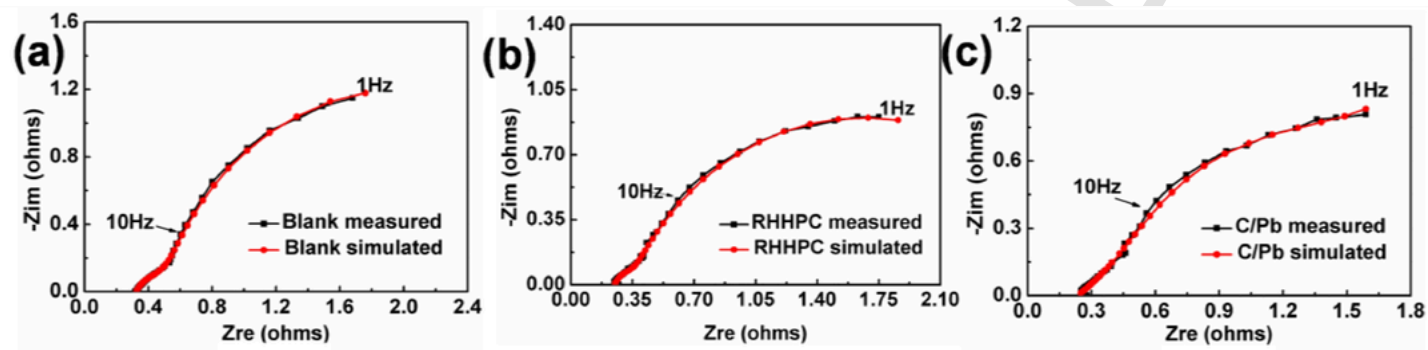

Fig. 6. Nyquist plot of (a) blank, (b) RHHPC and (c) C/Pb composite electrodes at open circuit potential.
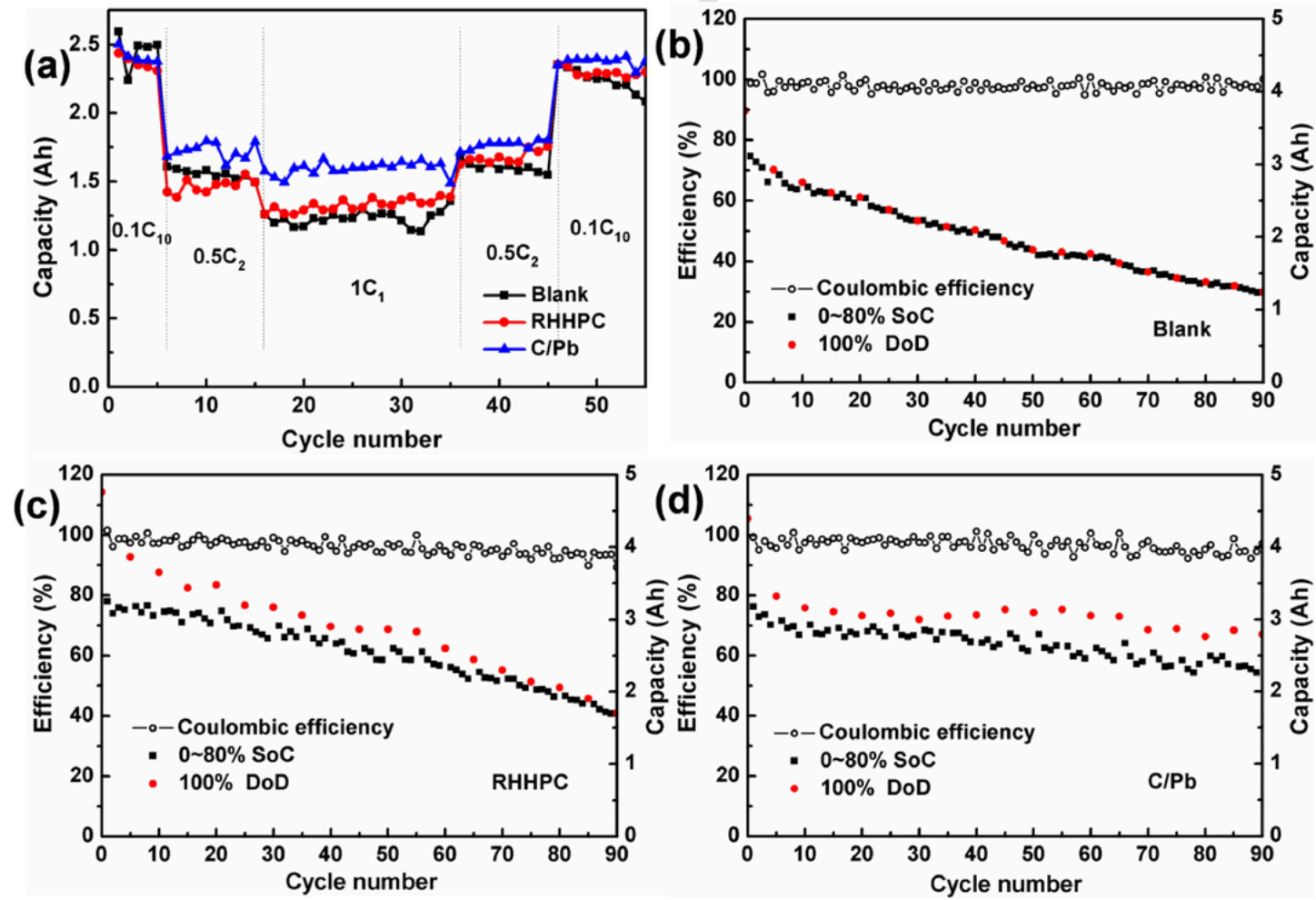

Fig. 7. (a) Rate capabilities of the cells, the performances under PSoC operation of (b) blank, (c) RHHPC and (d) C/Pb composite cells. 

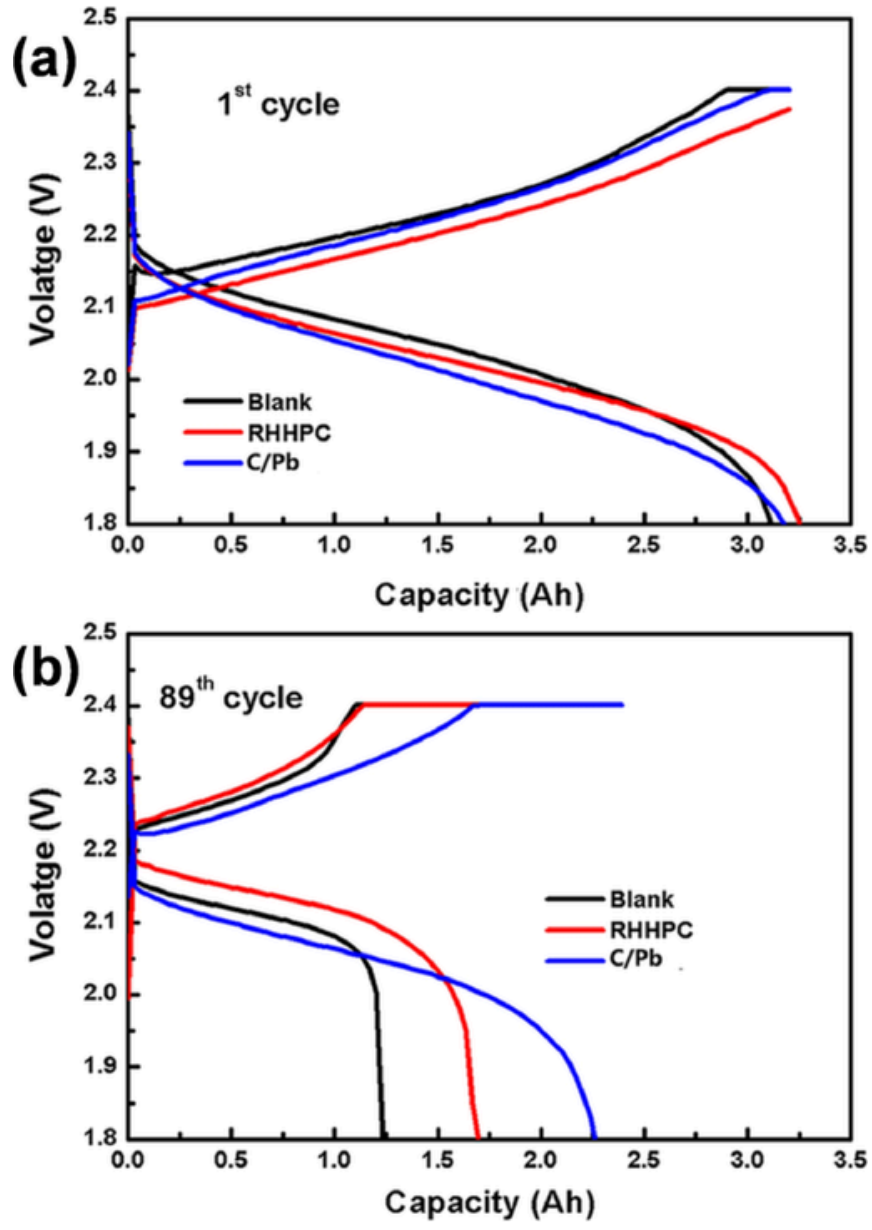

Fig. 8. Charge/discharge profiles of the cells (a) in the 1st cycle and (b) in the 89th cycle under PSoC operation.
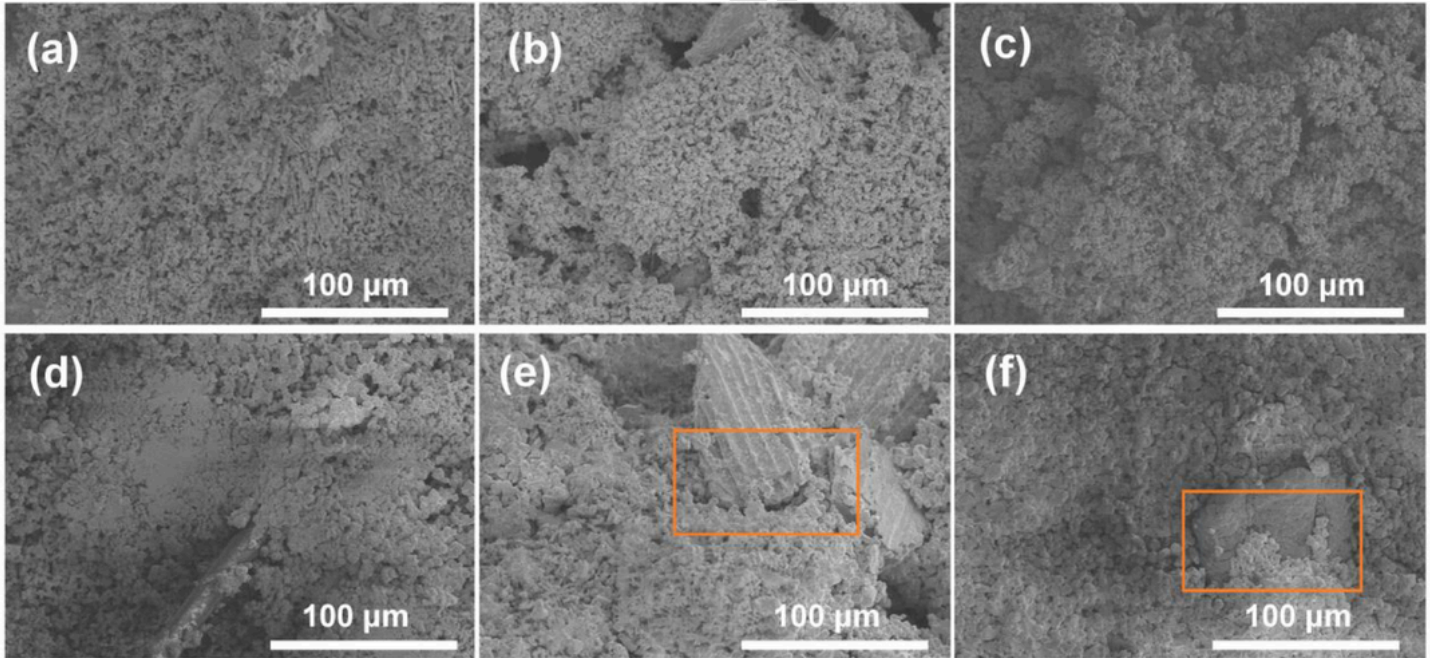

Fig. 9. SEM images magnified $\times 500$ of the (a) blank, (b) RHHPC and (c) C/Pb anodes of cells after the formation process; the (d) blank, (e) RHHPC and (f) C/Pb anodes of cells after PSoC operation. 
Table 5

Results of specific surface areas and pore size distributions of lead-carbon anodes of cells after the formation process and after PSoC operation.

\begin{tabular}{lllllll}
\hline $\begin{array}{l}\text { Lead-carbon } \\
\text { anode }\end{array}$ & \multicolumn{3}{l}{ After the formation process. } & \multicolumn{3}{l}{ After PSoC operation. } \\
\hline & $S_{\mathrm{BET}}$ & $V_{\text {meso }}$ & $V_{\text {mirco }}$ & $S_{\mathrm{BET}}$ & $V_{\text {meso }}$ & $V_{\text {mirco }}$ \\
\hline & $\left(\mathrm{m}^{2} \mathrm{~g}^{-1}\right)$ & $\left(\mathrm{cm}^{3} \mathrm{~g}^{-1}\right)$ & $\left(\mathrm{cm}^{3} \mathrm{~g}^{-1}\right)$ & $\left(\mathrm{m}^{2} \mathrm{~g}^{-1}\right)$ & $\left(\mathrm{cm}^{3} \mathrm{~g}^{-1}\right)$ & $\left(\mathrm{cm}^{3} \mathrm{~g}^{-1}\right)$ \\
Blank & 1.9 & 0.007 & 0 & 1.5 & 0.005 & 0 \\
RHHPC & 17.8 & 0.011 & 0.008 & 19.6 & 0.012 & 0.009 \\
$\mathrm{C} / \mathrm{Pb}$ & 12.7 & 0.009 & 0.006 & 12.9 & 0.010 & 0.006 \\
composite & & & & & & \\
\hline
\end{tabular}
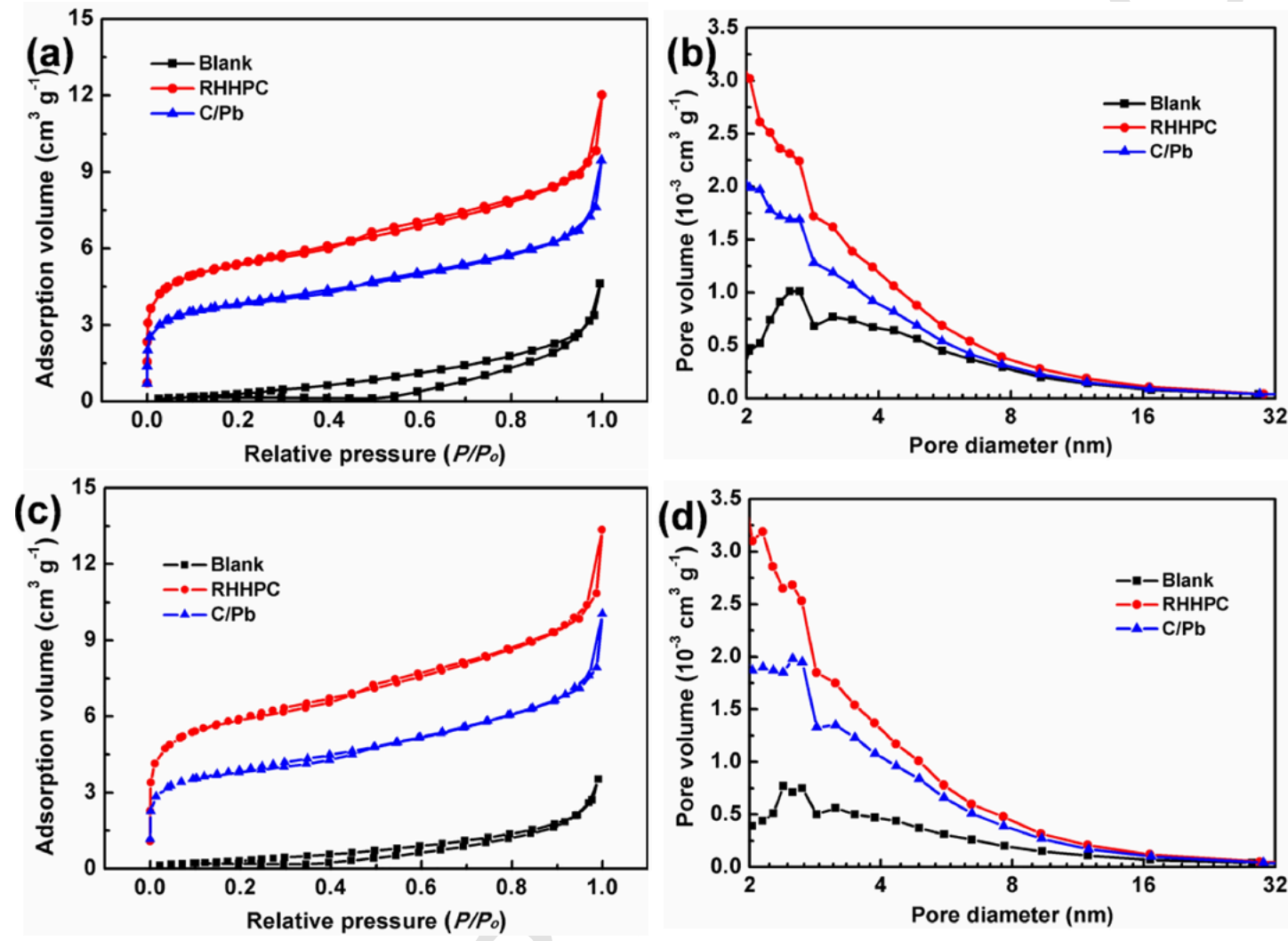

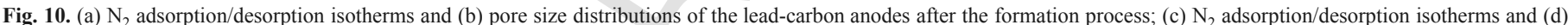
pore size distributions of the lead-carbon anodes after PSoC operation. 


\section{References}

[1] H. Bode, Lead-Acid Batteries, John Wiley \& Sons, New York, USA, 1977243-244.

[2] P.T. Moseley, D.A.J. Rand, B. Monahov, J. Power Sources 219 (2012) 75-79.

[3] A. Czerwinski, S. Obrebowski, J. Kotowski Z. Rogulski, J. Skowronski, M. Bajsert, M. Przystałowski, M. Buczkowska-Biniecka, E. Jankowska, M. Baraniak, J. Rotnicki, M. Kopczyk, J. Power Sources 195 (2010) 7530-7534.

[4] R.H. Newnham, W.G.A. Baldsing, J. Power Sources 107 (2002) 273-279.

[5] P.T. Moseley, Electrochemical Energy Storage for Renewable Sources and Grid, Elsevier, 2014207-210.

[6] J. Anderson, In: Proceedings of the Energy Storage-2nd Renewable Power Generation \& Energy Storage System Industry Outlook, Beijing, China, 2011.

[7] S. Sampath, D.D. Sarma, A.K. Shukla, ACS Energy Lett. 1 (2016) 1162-1164.

[8] D. Pavlov, Lead-Acid Batteries: Science and Technology, Elsevier B.V., Amsterdam, 2011340-342.

[9] P.T. Moseley, D.A.J. Rand, J. Power Sources 133 (2004) 104-109.

[10] Y. Guo, S. Tang, G. Meng, S. Yang, J. Power Sources 191 (2009) 127-133.

[11] L.T. Lam, N.P. Haigh, C.G. Phyland, A.J. Urban, J. Power Sources 133 (2004) $126-134$.

[12] K. Nakamura, M. Shiomi, K. Takahashi, M. Tsubota, J. Power Sources 59 (1996) 15-17.

[13] M. Shiomi, T. Funato, K. Nakamura, K. Takahashi, M. Tsubota, J. Power Sources 64 (1997) 147-152.

[14] M. Calábe, K. Micka, P. Křivák, P. Bača, J. Power Sources 158 (2006) 864-867.

[15] L.T. Lam, R. Louey, J. Power Sources 158 (2006) 1140-1148.

[16] P.T. Moseley, D.A.J. Rand, K. Peters, J. Power Sources 295 (2015) 268-274.

[17] P.T. Moseley, J. Power Sources 191 (2009) 134-138.

[18] P. Bača, K. Micka, P. Křivík, K. Tonar, P. Tošer, J. Power Sources 196 (2011) 3988-3992.

[19] K. Micka, M. Calábek, P. Bača, P. Křivák, R. Lábus, R. Bilko, J. Power Sources 191 (2009) 154-158.

[20] D. Pavlov, P. Nikolov, T. Rogachev, J. Power Sources 195 (2010) 4444-4457.

[21] D. Pavlov, P. Nikolov, T. Rogachev, J. Power Sources 196 (2011) 5155-5167.

[22] W.L. Zhang, H.B. Lin, H.Y. Lu, D.C. Liu, J. Yin, Z.Q. Lin, J. Mater. Chem. A 3 (2015) 4399-4404.

[23] J. Xiang, P. Ding, H. Zhang, X. Wu, J. Chen, Y. Yang, J. Power Sources 241 (2013) 150-158.

[24] D. Pavlov, P. Nikolov, J. Power Sources 242 (2013) 380-399.

[25] A. Jaiswal, S.C. Chalasani, J. Energy Storage 1 (2015) 15-21.

[26] K.K. Yeung, X. Zhang, S.C.T. Kwok, F. Ciucci, M.M.F. Yuen, RSC Adv. 5 (2015) 71314-71321.

[27] B. Hong, L. Jiang, H. Xue, F. Liu, M. Jia, J. Li, Y. Liu, J. Power Sources 270 (2014) 332-341.

[28] D. Cericola, M. Spahr, J. Power Sources 324 (2016) 41-44.

[29] D. Pavlov, T. Rogachev, P. Nikolov, G. Petkova, J. Power Sources 191 (2009) 58-75.

[30] J. Settelein, H. Lorrmann, G. Sextl, , Electrochim. Acta 233 (2017) 173-180.

[31] W.L. Zhang, J. Yin, Z.Q. Lin, J. Shi, C. Wang, D.B. Liu, Y. Wang, J.P. Bao, H.B. Lin, J. Power Sources 342 (2017) 183-191.

[32] C. O'Donnell, M. Schiemann, In: Proceedings of the Battcon Stationary Battery Conference, Marco Island, 2008.
[33] T. Lam, H. Ceylan, N.P. Haigh, T. Lwin, D.A.J. Rand, J. Power Sources 195 (2010) 4494-4512.

[34] M.A. Deyab, RSC Adv. 5 (2015) 41365-41371.

[35] Y.B. Kamenev, A.V. Kiselevich, E.I. Ostapenko, V.N. Varypaev, Russ. J. Appl. Chem. 77 (2004) 1455-1459.

[36] Y.F. Zhang, X. Liu, J.C. Ca, R. Zhao, Z.Q. Li, H.Y. Chen, Ionics 21 (2015) 2693-2700.

[37] D. Pavlov, P. Nikolov, J. Electrochem. Soc. 159 (2012) A1215-A1225.

[38] B. Hong, X.Y. Yu, L.X. Jiang, H.T. Xue, F.Y. Liu, J. Li, Y.X. Liu, RSC Adv. 4 (2014) 33574-33577.

[39] L. Wang, H. Zhang, G. Cao, W. Zhang, H. Zhao, Y.S. Yang, Electrochim. Acta 186 (2015) 654-663.

[40] L. Zhao, B.S. Chen, D.L. Wang, J. Power Sources 231 (2013) 34-38.

[41] L. Zhao, B.S. Chen, J.Z. Wu, D.L. Wang, J. Power Sources 248 (2014) 1-5.

[42] L. Zhao, W. Zhou, Y.B. Shao, D.L. Wang, RSC Adv. 4 (2014) 44152-44157.

[43] J.Y. Xiang, C. Hu, L.Y. Chen, D. Zhang, P. Ding, D. Chen, H. Liu, J. Chen, X.Z. Wu, X.K. Lai, J. Power Sources 328 (2016) 8-14

[44] H.T. Xue, L.X. Jiang, Z.H. Li, X.J. Lu, Battery Bimon. 4 (2015) 202-205, (in Chinese).

[45] J.L. Ma, D.L. Wang, F. Chen, X.M. Fang, J. Inorg. Chem. 9 (2013) 1935-1941, (in Chinese)

[46] P.Y. Tong, R.R. Zhao, R.B. Zhang, F.Y. Yi, G. Shi, A.J. Li, H.Y. Chen, J. Power Sources 268 (2015) 91-102.

[47] L. Wang, W. Zhang, L. Gu, Y. Gong, G. Cao, H. Zhao, Y. Yang, H. Zhang, Electrochim. Acta 222 (2016) 376-384.

[48] L. Wang, H. Zhang, W. Zhang, G. Cao, H. Zhao, Y. Yang, Mater. Lett. 206 (2017) 113-116.

[49] D.C. Liu, W.L. Zhang, H.B. Lin, Y. Li, H.Y. Lu, Y. Wang, RSC Adv. 5 (2015) 19294-19300.

[50] L.M. Ang, T.S.A. Hor, G.Q. Xu, C.H. Tung, S.P. Zhao, J.L.S. Wang, Carbon 38 (2000) 363-372.

[51] L.M. Ang, T.S.A. Hor, G.Q. Xu, C.H. Tung, S. Zhao, J.L.S. Wang, Chem. Mater. 11 (1999) 2115-2118.

[52] V.R Nagarajan, P.R. Kharel, S.K. Putatunda, G. Lawes, Mater. Sci. Eng. B $151(2008)$ 191-194.

[53] Z. Tang, J. Wang, X. Mao, H. Shao, Q. Chen, Z. Xu, J. Zhang, J. Power Sources 168 (2007) 49-57.

[54] P. Ruftschi, J. Power Sources 2 (1977/78) 3-24.

[55] S.M. Kumar, S. Ambalavanan, S. Mayavan, RSC Adv. 4 (2014) 36517-36521.

[56] M. Saravanan, M. Ganesan, S. Ambalavanan, J. Power Sources 251 (2014) 20-29.

[57] M.S. Rahmanifar, Electrochim. Acta 235 (2017) 10-18

[58] L. Chladila, O. Čecha, P. Vanýsek, ECS Trans. 74 (1) (2016) 147-155.

[59] M. Dimitrov, D. Pavlov, T. Rogachev, M. Matrakova, L. Bogdanova, J. Power Sources 140 (2005) 168-180.

[60] S. Zhang, H. Zhang, J. Cheng, W. Zhang, G. Cao, H. Zhao, Y. Yang, J. Power Sources 334 (2016) 31-38.

[61] D.P. Boden, D.V. Loosemore, M.A. Spence, T.D. Wojcinski, J. Power Sources 195 (2010) 4470-4493.

[62] S. Meenakorn, P. Termsuksawad, S. Phiboonkulsumrit, J. Mater. Eng. Perform. 24 (2015) 45-52.

[63] A. Kirchev, F. Mattera, E. Lemaire, K. Dong, J. Power Sources 191 (2009) $82-90$. 